\title{
New approach to trophic state assessment of running waters in Poland
}

\author{
Elena Neverova-Dziopak \\ Zbigniew Kowalewski \\ AGH University of Science and Technology, Aleja Mickiewicza 30 (C-4), 30-059Kraków, e-mail: elenad@agh.edu.pl
}

\begin{abstract}
The problem of eutrophication has, since the 1970s, reached a global scale and become a problem of principal importance due to its negative consequences, which could result in the total loss of biospheric functions of aquatic ecosystems, and also their economic role. The increasing intensity of eutrophication processes and their specificity in various types of waters requires the development of special methods of control and protection of aquatic ecosystems. As a result of the high dynamism of eutrophication and its dependence on different factors (hydrological, hydrodynamic, hydrobiological, morphological, edaphic and climatic conditions), the assessment of trophic status in order to control and manage this process is very complicated. The evaluation of the consequences of anthropogenic eutrophication and the scale of its development can be provided only on the basis of systematic observation during a multi-annual period.

Careful analysis of the state of knowledge on the issues related to eutrophication, especially the methods of trophic status assessment, have allowed us to conclude that at present there is no universal methodology for the assessment of the surface water trophic level, while the existing methods have various shortcomings, which reduce the reliability of the results and complicate the development of appropriate technical, organizational and legal protection measures. A critical analysis of trophic status assessment approaches for different categories of waters has also allowed us to state that there is no an appropriate method for the assessment of the trophic status of running waters, since almost all existing assessment methods are developed for lakes and coastal areas.

This paper presents an original approach elaborated for the assessment of the trophic state of running waters based on the statistical analysis of long-term monitoring data and numerical criterion ITS, which allows for a simple and low-cost monitoring of eutrophication suitable for the solving of different application tasks in the field of surface water protection.
\end{abstract}

Keywords: eutrophication, biotic balance, trophic state assessment, integral criterion.

Submitted 15 April 2013, received 13 June 2013, accepted 13 November 2013

\section{Introduction}

Currently, the processes of the development and transformation of aquatic ecosystems run much faster than before because they are conditioned not only by natural factors acting at the scale of geological processes but also by anthropogenic factors. The global processes, whose rates have increased significantly in recent decades, also include the process of anthropogenic eutrophication, which has spread in many bodies of water and has led to the deterioration of surface water quality throughout the world.

Since the 1970s, anthropogenic eutrophication has been treated as a priority issue because of its negative consequences, which can result in the total violation of biospheric functions of aquatic ecosystems and the loss of their economic value.

It is worth noting that "water blooms", which are the most spectacular symptom of eutrophication, arise as a result of anthropogenic impact and can be regarded as a response of the ecosystem and its adaptation to changing environmental conditions - in other words - a new stage of its existence.

"Blooms" are, on the one hand, an indicator of the deterioration of the sanitary-hygienic characteristic of water, and, on the other hand, are the source of secondary pollution that results in negative health, environmental and economic consequences.

The increasing intensity of eutrophication processes and their specificity in various types of waters requires the elaboration of special methods of monitoring, control and protection of aquatic ecosystems.

As a result the high dynamism of eutrophication and its dependence on different factors (hydrological, hydrodynamic, hydrobiological, morphological, edaphic and climatic conditions) the evaluation of water trophic status, required for the purposes of eutrophication control and management, is a very complicated task.

The analysis of the state of knowledge of the examined issues shows that the appropriate assessment of water trophic status, the scale of aquatic ecosystems changes, and of water quality is very difficult due to the lack of long-term observation of a number of synchronically measured hydrobiological parameters. In addition, the organization of the system of monitoring the eutrophication process is unsatisfactory. Moreover, there is no uniform methodology for the assessment of the water trophic level, as well as no universal low-cost indicators of eutrophication. 


\section{Eutrophication in rivers}

Freshwater lakes and reservoirs are most sensitive to the adverse consequences of eutrophication, but in recent decades, due to intensive anthropogenic activity, this process has occurred more and more often in marine ecosystems and running waters.

The length of the river network in Poland is quite substantial $-74714 \mathrm{~km}, 52 \%$ of which is artificially regulated. On the one hand, this is one of the elements of the flood control system and meets economic needs. But such a drastic intervention in the environment leads to the loss of a river's natural values, changes a river's biota structure and consequently reduces its ability to self-clean - this, at least, leads to the intensification of eutrophication processes. Any hydrographic network basin is dominated by medium-sized and small rivers - these are heavily dependent on the characteristic and anthropogenic activities in the catchment area that greatly affect the state of river ecosystems (GIOŚ 2010). Not so long ago the main sources of river pollution were municipal and industrial wastewaters. In recent years, the pollution load discharged to the rivers from point sources has decreased as a result of the construction of a number of new wastewater treatment plants. But at the same time the amount of surface run-off from agricultural areas and the negative impact of river navigation and hydropower has increased.

The assessment of the trophic status of rivers is much more complicated than that of lakes and reservoirs because the symptoms of this process and its course vary according to the type of river (Dodds et al. 1998). Traditionally, eutrophication level is assessed on the basis of numerical values of indicators, developed by different authors, which are elaborated mainly for lakes or estuaries with consideration of local geographical conditions. However, as practice shows, due to the large number of factors that determine the development of eutrophication processes, the traditional approach to assessing the trophic state of rivers very often gives unreliable or contradictory results and makes it difficult to assess the real situation. The prevention of the intensification of the eutrophication process and protection against its negative consequences requires the development of a specific monitoring system, and also the elaboration of indicators and assessment methods of water trophic status in accordance with modern requirements.

Currently there is no universal methodology for assessing the level of eutrophication. What is more, various EU directives and documents do not specify the procedures for trophic status assessment of surface waters. For the purposes of the evaluation of the development of the eutrophication process, different countries use different sets of indicators and numerical values .

The great importance of natural features of rivers and their role in the national economy makes it necessary to search for effective ways of protecting against eutrophication and its negative consequences. The protective mea- sures, in turn, should be based on reliable information on the current state of water, obtained on the basis of simple, low-cost indicators of eutrophication, which are easy to use and interpret and which are also suitable for application purposes. These indicators form the basis for the formulation of mathematical models, forecasting, the evaluation of the protection the effectiveness of investments, the estimation of the impact of wastewater on the water quality of a receiver, as well as for the establishment of permissible pollution loads and the optimal degree of wastewater treatment, especially for the removal of nutrients.

\section{Assessment of trophic state of rivers}

Presently there is no single opinion on the choice of the parameters used to determine the trophic status, and also no universal classification of trophic water status (LopezBernal 2003).

In practice the most widely-used application found the following indicators of eutrophication: Secchi disk transparency; concentrations of phosphorus, nitrogen, oxygen and chlorophyll; level of primary production; algae biomass, zoobenthos, etc. Numerical values of the indicators for different trophic levels have been developed by different authors in numerous publications (Bogestrand 2004, Cierniawska-Kusza 2003, Ferreira et al. 2011, Karydis 2009, Kristensen et al. 1996, Smith 2007).

An alternative to the traditionally used indicators of eutrophication are so-called aggregated indicators - the indexes of trophic state. They are based on the calculation of the numerical value of the index on the basis of the correlation between the main factors of eutrophication (mainly chlorophyll-a and different forms of nitrogen and phosphorus) established by different authors together with their boundary values for each trophic level. The aim of the method based on these indexes is to provide a more reliable assessment of trophic state and the possibility of quick and easy monitoring of water (which in the case of the use of the set of separate indicators is not always possible). Such indexes were elaborated and developed by Vollenweider, Carlson, Burns, by HELCOM, NEEA (National Estuarine Eutrophication Assessment) and OECD (Organisation for Economic Co-operation and Development) (Carlson 1975, Giovanardi et al. 2004, BPRC, Bricker et al. 2003, HC 2007, Soszka 2009).

In this paper the authors present an essentially new approach to the assessment of the trophic status of running waters, which assumes the use of the integral criterion of trophic state ITS (Neverova-Dziopak 2010). The theoretical foundation of the ITS index (Index of Trophical State) is the state of the balance of production and destruction of organic matter produced by algae, which is known as biotic balance. Changes in the biotic balance lead to changes in the gas balance of water, and, thus, the concentrations and ratios of oxygen and carbon dioxide (Dojlido 1995, Neverova-Dziopak 2010). In an aquatic environment the content of oxygen can be expressed by the saturation of 
water with oxygen, and the $\mathrm{CO}_{2}$ content can be expressed by $\mathrm{pH}$ value. Changes in $\mathrm{CO}_{2}$ concentration lead to changes in $\mathrm{pH}$ value, which results from the carbonate balance, i.e. the state of a certain proportion between bicarbonate and carbonate ions according to the following equation:

$$
\mathrm{CO}_{2}+\mathrm{H}_{2} \mathrm{O} \leftrightarrow \mathrm{H}_{2} \mathrm{CO}_{3} \leftrightarrow \mathrm{H}^{+}+\mathrm{HCO}_{3}^{-} \leftrightarrow \mathrm{H}^{+}+\mathrm{CO}_{3}^{2-}
$$

It follows that the trophic state can be described by the balance of $\mathrm{CO}_{2}$ and $\mathrm{O}_{2}$ concentrations, while these concentrations can be described by $\mathrm{pH}$ value and the degree of saturation of water with oxygen. The ratio of $\mathrm{pH}$ value and oxygen saturation of water is therefore a function of the biotic balance. At the same level of oxygen saturation, the higher the $\mathrm{pH}$ value of water is, the higher the trophic state is. The $\mathrm{pH}$ value at normal oxygen saturation was proposed as the integral index of trophic state ITS, which can be calculated according to the equation (2):

$$
\text { ITS }=\Sigma \mathrm{pH}_{\mathrm{i}} / \mathrm{n}+\mathrm{a}\left(100-\Sigma\left[\mathrm{O}_{2} \%\right] / \mathrm{n}\right)
$$

where:

$\mathrm{pH}_{\mathrm{i}}$ - the value of $\mathrm{pH}$

$\left[\mathrm{O}_{2} \%\right]$ - the value of oxygen saturation measured synchronically with $\mathrm{pH}$

a-empirical coefficient

$\mathrm{n}$ - measurements number

ITS index values in waters of different trophic levels are shown on Fig. 1.

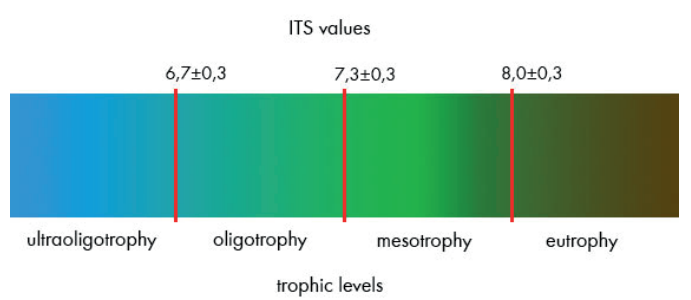

Figure 1. ITS index values (Neverova-Dziopak 2010)

The aim of this study was to show the possibility of the application of the integral criterion ITS for trophic status assessment of different types of running waters.

\section{Methodology of research}

Aquatic ecosystems, like all other ecosystems, are characterized by extremely complicated organization. A huge variety of constantly changing relationships between numerous different factors is the characteristic feature of such ecosystems. Proper evaluation of the nature of these relationships and of ecosystem reaction to the impact of various factors can be based only on a complex analysis of numerous data obtained through monitoring. The most appropriate approach for such analysis is the application of the methods of mathematical statistics - this method allows one to obtain reliable and objective results.
Therefore, the methodology of the research was based on the methods of correlation and regression analysis of data obtained through long-term monitoring of running waters in order to determine the character of the relationship between the selected parameters.

\section{Results of statistical analysis}

The basis for ITS application as a trophic state index is the existence of a linear correlation between $\mathrm{pH}$ and oxygen saturation of water. The studies were carried out for the assessment of the trophic level of the rivers within the Małopolskie Voivodship area. According to the typology of rivers developed in 2004 by the Institute of Meteorology and Water Management (IMGiW), the Institute of Environmental Protection (IOŚ), the Polish Geological Institute (PIG) and the Maritime Institute (IM), 15 types of the rivers were identified (WIOŚ Kraków 2011). The correlation-regression analysis of the ten-year monitoring database of different types of rivers has confirmed the existence of a close relationship between $\mathrm{pH}$ value and oxygen saturation of water in rivers undergoing the process of eutrophication. The Pearson correlation coefficient ( $r$ ) for studied rivers varies between the limits of 0,60-0,97. Table 1 presents the results of statistical analysis for chosen measurement points within the Małopolskie Voivodship area (Kowalewski 2012).

\section{Verification of ITS criterion applicability}

In order to confirm the validity of the proposed method for trophic state assessment of running water, it was necessary to conduct a verification (Fig. 2-4). Since the most common traditional indicators of eutrophication are nitrogen, phosphorus and chlorophyll, the verification was based on a comparison of the result of trophic state assessment conducted using the ITS criterion, and the numerical values of the above-mentioned traditional indicators developed by various authors. The database was compiled from the results of monitoring performed by Voivodship Inspectorates for Environmental Protection (WIOŚ) and covering 264 measurement points (Kowalewski 2012).

Verification of the applicability of the ITS index for trophic state assessment of running waters, carried out by

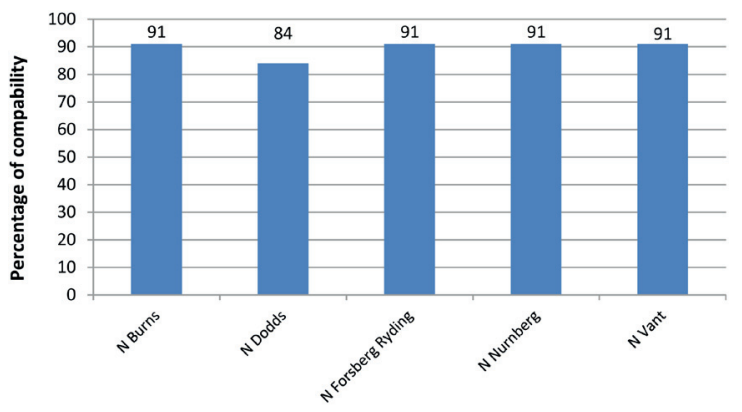

Figure 2. Percentage of compatibility of assessments carried out on the basis of total nitrogen content and ITS value 
Table 1. The results of statistical analysis of monitoring data

\begin{tabular}{|c|c|c|c|c|c|}
\hline Type of river and measurement point & $\begin{array}{c}\text { Period of } \\
\text { monitoring }\end{array}$ & $\begin{array}{c}\text { Number of } \\
\text { measurements }\end{array}$ & $r$ & ITS & $\begin{array}{c}\text { The result of } \\
\text { assessment }\end{array}$ \\
\hline 7 Sanka Liszki 3.3 km & $2001-2010$ & 114 & 0.65 & 8.0 & eutrophic \\
\hline 8 Biała Przemsza poniżej Kluczy 35 km & $2008-2010$ & 30 & 0.97 & 8.0 & eutrophic \\
\hline 9 Dłubnia Kończyce 10.4 km & $2001-2007$ & 80 & 0.77 & 8.1 & eutrophic \\
\hline 9 Dłubnia Nowa Huta 0.7 km & $2001-2007$ & 62 & 0.95 & 8.1 & eutrophic \\
\hline 9 Prądnik Białucha Ujście 0.5 km & 2001-2009 & 78 & 0.91 & 8.1 & eutrophic \\
\hline 9 Rudawa Kraków 0.1 km & $2000-2011$ & 97 & 0.90 & 8.1 & eutrophic \\
\hline 9 Rudawa Podkamycze 9.3 km & $2000-2009$ & 102 & 0.82 & 7.9 & mesotrophic \\
\hline 12 Biały Dunajec Poronin 17.7 km & $2001-2009$ & 65 & 0.83 & 8.4 & eutrophic \\
\hline 12 Lipnica ujście do zb. Orawskiego $0.2 \mathrm{~km}$ & 2004-2009 & 68 & 0.66 & 8.0 & eutrophic \\
\hline 12 Zubrzyca do Czarnej Orawy $0.2 \mathrm{~km}$ & $2004-2007$ & 20 & 0.71 & 8.0 & eutrophic \\
\hline 14 Biała Tarnów 0.4 km & $2001-2007$ & 82 & 0.63 & 8.1 & eutrophic \\
\hline 14 Czarna Orawa Jabłonka 25 km & $2000-2011$ & 166 & 0.88 & 8.1 & eutrophic \\
\hline 14 Raba poniżej oczyszczalni Myślenice 69 km & $2001-2007$ & 71 & 0.97 & 8.0 & eutrophic \\
\hline 14 Raba powyżej Stróży 80.6 km & $2001-2007$ & 73 & 0.88 & 8.1 & eutrophic \\
\hline 14 Skawa powyżej Suchej Beskidzkiej 45.7 km & $2001-2006$ & 50 & 0.76 & 8.0 & eutrophic \\
\hline 14 Skawa Wadowice $21.2 \mathrm{~km}$ & $2001-2006$ & 56 & 0.94 & 8.0 & eutrophic \\
\hline 15 Dunajec Czerwony Klasztor 168.3 km & $2002-2007$ & 72 & 0.60 & 7.7 & mesotrophic \\
\hline 15 Dunajec powyżej ujścia Popradu 119 km & $2001-2006$ & 70 & 0.93 & 8.4 & eutrophic \\
\hline 15 Dunajec Świniarsko 110.8 km & $2001-2007$ & 64 & 0.88 & 8.4 & eutrophic \\
\hline 15 Skawa Zator $4.2 \mathrm{~km}$ & $2001-2007$ & 76 & 0.90 & 7.9 & mesotrophic \\
\hline 15 Soła Kęty 16.8 km & $2004-2007$ & 25 & 0.97 & 7.7 & mesotrophic \\
\hline 19 Dunajec Biskupice Radłowskie 19.6 km & 2001-2007 & 82 & 0.67 & 8.2 & eutrophic \\
\hline 19 Raba Gdów 50.2 km & $2001-2006$ & 54 & 0.91 & 8.1 & eutrophic \\
\hline 19 Raba Kłaj 31.2 km & 2001-2006 & 69 & 0.85 & 8.1 & eutrophic \\
\hline 19 Wisła Niepołomice $102 \mathrm{~km}$ & 2001-2006 & 52 & 0.80 & 7.8 & mesotrophic \\
\hline 19 Wisła powyżej Krakowa 66.4 km & $2001-2006$ & 70 & 0.82 & 7.8 & mesotrophic \\
\hline 19 Wisła powyżej ujęcia Szreniawy 145.3 km & $2004-2007$ & 92 & 0.94 & 7.8 & mesotrophic \\
\hline 19 Wisła Słupiec $209.3 \mathrm{~km}$ & 2001-2006 & 52 & 0.94 & 8.1 & eutrophic \\
\hline 21 Skawa Jordanów 71.1 km & 2001-2006 & 52 & 0.94 & 8.1 & eutrophic \\
\hline 21 Wisła Łączany 38 km & 2001-2006 & 68 & 0.78 & 7.7 & mesotrophic \\
\hline 26 Drwinka Świniary 2 km & 2001-2009 & 50 & 0.68 & 7.6 & mesotrophic \\
\hline
\end{tabular}

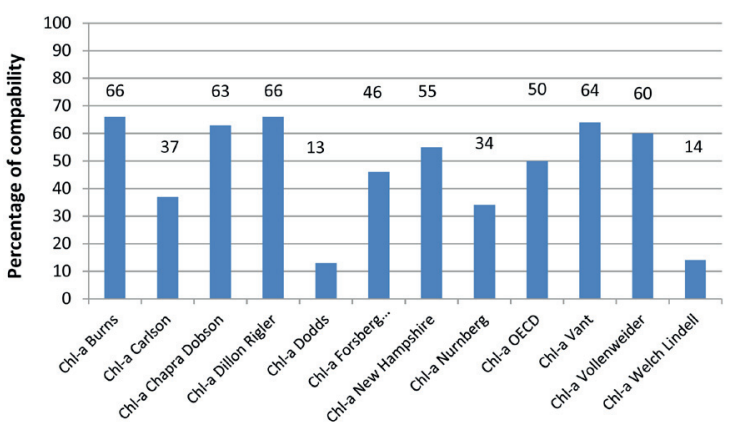

Figure 3. Percentage of compatibility of assessments carried out on the basis of total phosphorus content and ITS value

comparing the evaluation results obtained by the two described methods, allowed the authors to conclude, that the highest compatibility of the assessments was obtained with regard to ITS and nutrient content - on average it amounted to $90 \%$. While in the case of the comparison of

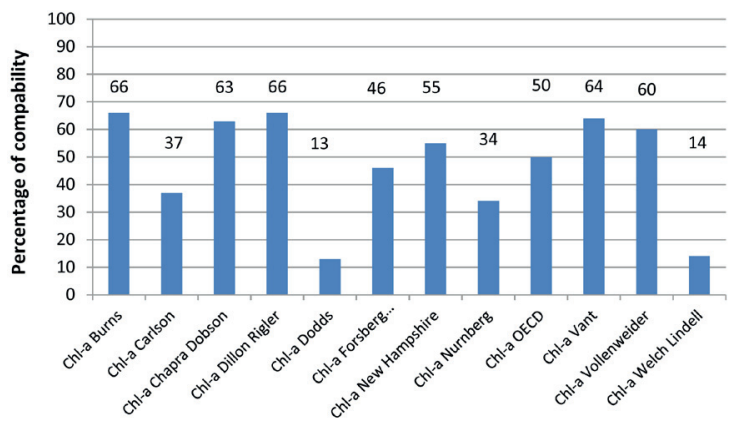

Figure 4. Percentage of compatibility of assessments carried out on the basis of chlorophyll-a content and ITS value

assessment results obtained on the basis of chlorophyll content, the compatibility was on average $47 \%$, which confirmed the low suitability of chlorophyll content for trophic state assessment of rivers. The high reliability of the results of verification, confirming the applicability of 
the ITS index for the assessment of the trophic state of running waters, was proven by statistical analysis of the comprehensive ten-year monitoring data bank.

The application of the proposed method of assessment based on the usage of the ITS criterion allows us to follow in a simple way the dynamics of the eutrophication pro- cess over a long-term period. The changes of trophic level estimated on the basis of the ITS index in different types of rivers in Małopolska during the last decade are shown on Fig. 5-12.

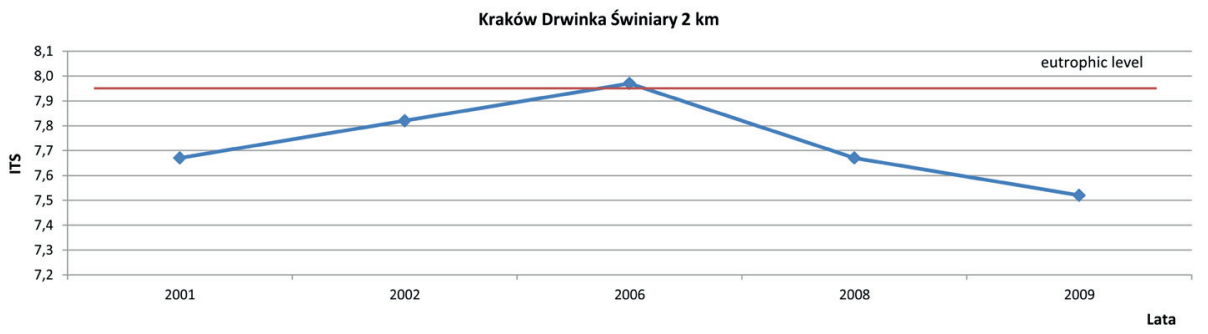

Figure 5. Long-term trophic level changes in the Drwinka river (type 26)

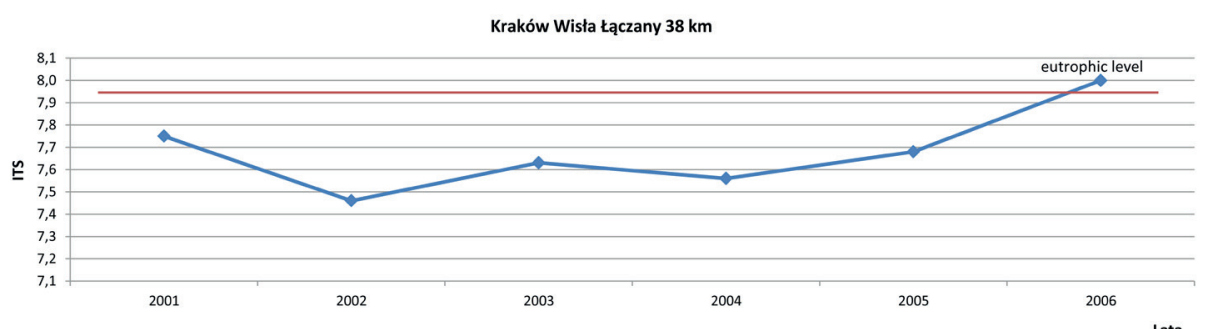

Figure 6. Long-term trophic level changes in the Wisła river (type 21)

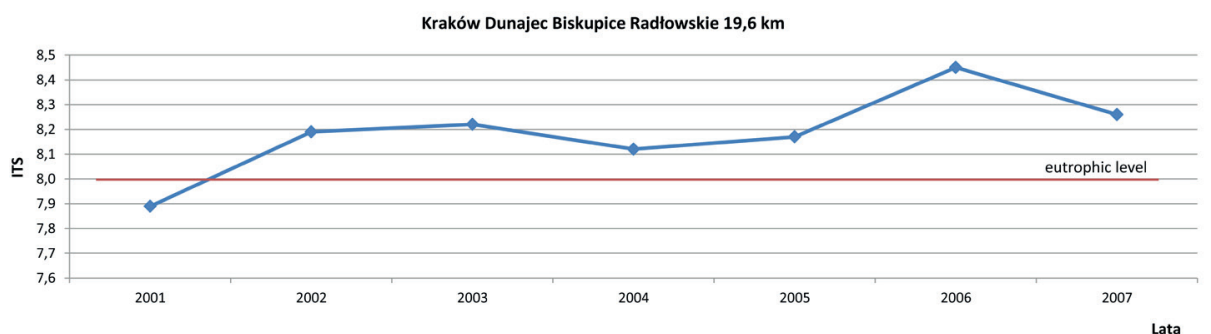

Figure 7. Long-term trophic level changes in the Dunajec river (type 19)

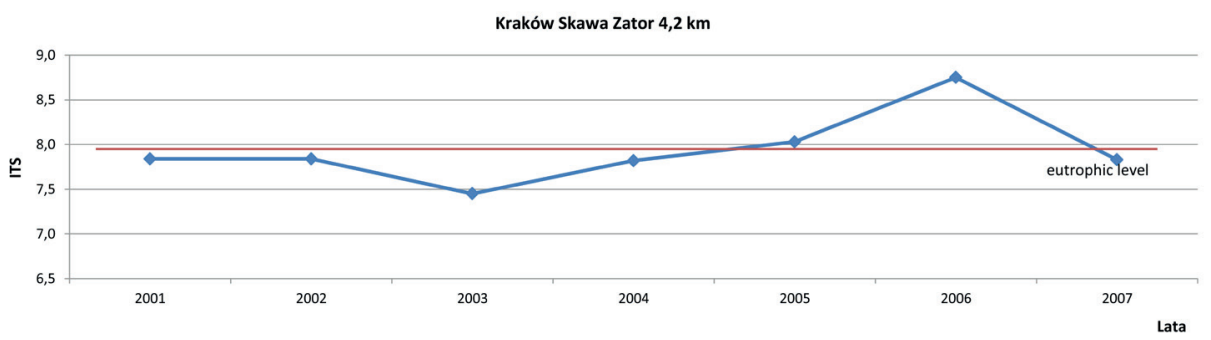

Figure 8. Long-term trophic level changes in the Skawa river (type 15)

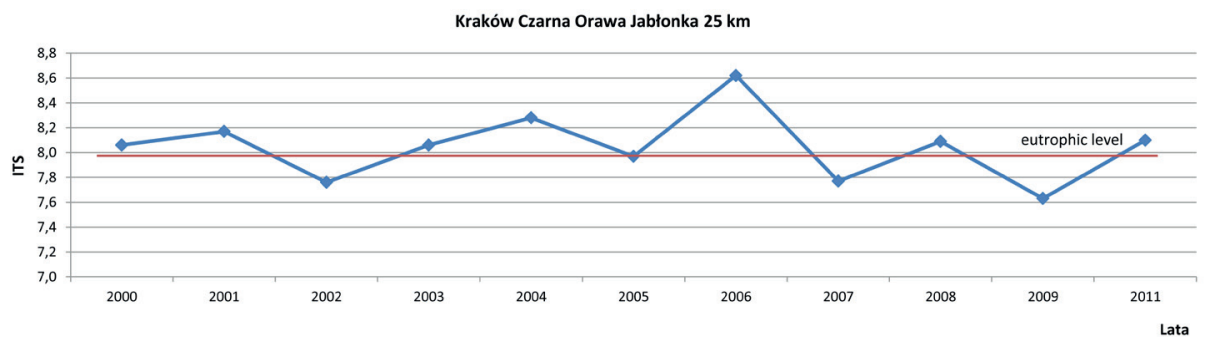

Figure 9. Long-term trophic level changes in the Czarna Orawa river (type 14) 


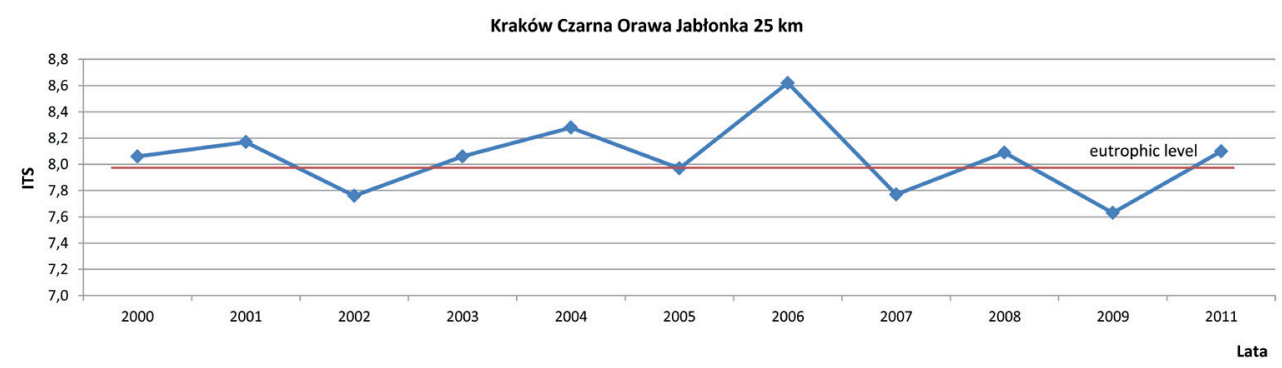

Figure 10. Long-term trophic level changes in the Dunajec river (type 12)

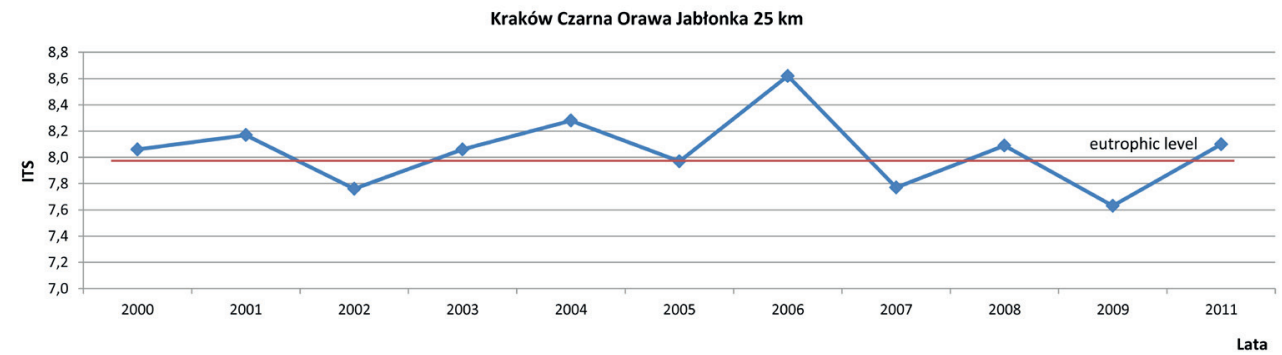

Figure 11. Long-term trophic level changes in the Rudawa river (type 9)

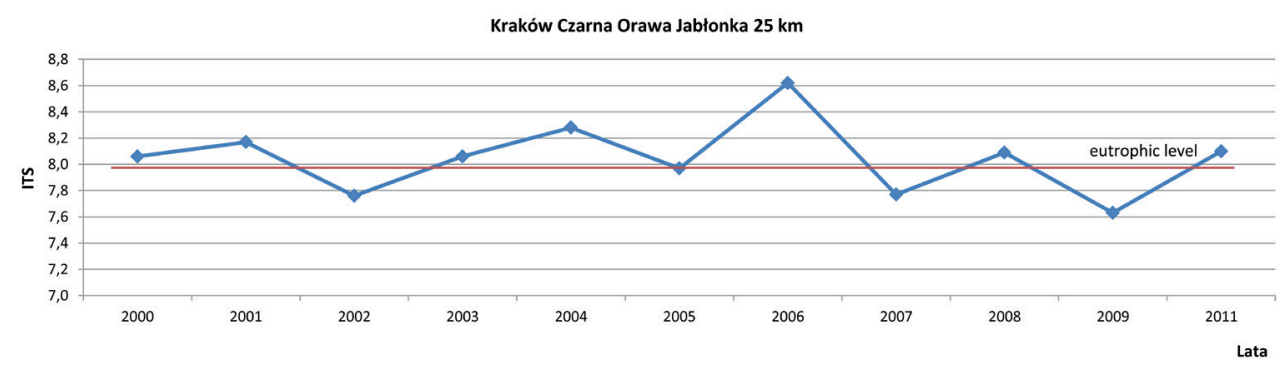

Figure 12. Long-term trophic level changes in the Sanka river (type 7)

\section{Conclusions}

1. The ITS index most accurately describes the state of the trophic state of surface water because it is based on the universal characteristic of water ecosystems - the state of biotic balance. It reflects the integral ecosystem response to the increase of nutrient content in water with consideration of its individual characteristics and properties.

2. ITS is based on limited data necessary for trophic state assessment and can be calculated on the basis of only two hydro-chemical characteristics: $\mathrm{pH}$ value and water saturation with oxygen.

3. ITS integrates information across time and space and is theoretically and technically reasonable.

4. ITS is suitable for the purpose of the formulation of forecasting mathematical models, the evaluation of the effectiveness of protective and remedial measures, and also for solving other application tasks.

5. In conclusion, it should be noted that the advantages of the ITS index in comparison with other methods of assessing the trophic status of water are the following: - high reliability and accuracy of assessment based on the ITS index,

- universal character of the ITS index is suitable for any type of running waters,
- considerable simplification of the monitoring of the eutrophication process and significant reduction of its costs.

Bibliography

Bogestrand J., 2004, Phosphorus in Lakes, EEA Indicator Fact Sheet, $125 \mathrm{pp}$

BPRC-Bay of Plenty Regional Council: Trophic Level Index, http://monitoring.boprc.govt.nz/ Environment/Trophic-Level-Index.aspx.

Bricker S.B., Ferreira J.G., Simas T., 2003, An integrated methodology for assessment of estuarine trophic status, Ecological Modelling, 169, 39-60

Carlson R., 1975, A trophic state index for Lakes, Limnology and Oceanography, 22 (2977), 361-369

Cierniawska-Kusza I., 2003, Biological Water Quality Assessment of the Ścinawa Niemodlińska River Based on the Biotic Index Method, Archives of Environment Protection, 29 (1), $29-46$

Dodds W.K., Jones J.R., Welch E.B., 1998, Suggested classification of stream trophic state: distributions of temperate stream types by chlorophyll, total nitrogen, and phosphorus, Water Research, 32 (5), 1455-1462

Dojlido J., 1995, Chemia wód powierzchniowych, Wydawnictwo Ekonomia i Środowisko, Białystok, 342 pp 
Ferreira J.G., Andersen J., Borja A., 2011, Overview of eutrophication indicators to assess environmental status within the European Marine Strategy Framework Directive Estuarine, Coastal and Shelf Science, 93 (2), 117-131

GIOŚ Główny Inspektorat Ochrony Środowiska, 2010, Raport o stanie środowiska w Polsce 2008, Warszawa

Giovanardi F., Vollenweider R., 2004, Trophic conditions of marine coastal waters: experience in applying the Trophic Index TRIX to two areas of the Adriatic and Tyrrhenian seas, Journal of Limnology, 63 (2), 199-218

Helsinki Commission, Danish EPA, 2007, Testing of the draft HELCOM eutrophication assessment tool (HEAT) in 45 basins and costal water bodies of the Baltic Sea, HELCOM EUTRO-PRO 5/2007

Karydis M., 2009, Eutrophication assessment of coastal waters based on, Global NEST Journal, 11 (4), 373-390

Kowalewski Z., 2012, Weryfikacja możliwości zastosowania integralnego kryterium do oceny stanu troficznego wód, rozprawa doktorska, AGH Kraków

Kristensen P., Bogestrand J., 1996, Surface Water Quality Moni- toring National, European Topic Center on Inland Waters, National Environmental Research Institute, Denmark

Lopez-Bernal K.E., 2003, Design of a watershed-based nitrogen trading system or the Big and Little Wood Rivers Watershed, Massachusetts Institute of Technology, Dept. of Civil and Environmental Engineering

Neverova-Dziopak E., 2010, Podstawy zarządzania procesem eutrofizacji antropogenicznej, Wydawnictwa Dydaktyczne AGH, Kraków, 131 pp

Smith V.H., 2007, Using primary productivity as an index of coastal eutrophication: the units of measurement matter, Journal of Plankton Research, 29 (1), 1-6

Soszka H., 2009, Problemy metodyczne związane z oceną stopnia eutrofizacji jezior na potrzeby wyznaczania stref wrażliwych na azotany, Woda-Środowisko-Obszary Wiejskie, 9 (1), 151-159

WIOŚ Wojewódzki Inspektorat Ochrony Środowiska w Krakowie, 2011, Raport o stanie środowiska w województwie małopolskim w 2010 roku, Kraków 